\title{
THE CONSTITUTIONAL DUTY TO ENGAGE IN COLLECTIVE BARGAINING
}

\section{Introduction}

The law regarding collective bargaining in South Africa has been interpreted in two ways; the Labour Relations Act (LRA) refers to a duty to bargain collectively, while the Constitution refers to a right to engage in collective bargaining. These two interpretations have been subjected to judicial criticism (SANDU v Minister of Defence 20033 SA 239 (T) l; SANDU v Minister of Defence 20044 SA 10 (T) II; and Minister of Defence v SANDU 20071 SA 422 (SCA) III (hereafter "SANDU I, II and III')). These cases are relevant in terms of the courts' interpretation of collective bargaining as a duty or freedom. They are currently the main cases dealing with this issue in South Africa. This has created doubt as to whether the distinction provides an acceptable basis to use the terms interchangeably, both by the courts as well as those involved in collective bargaining. The purpose of this paper is firstly to sketch the landscape of South Africa's collective bargaining jurisprudence, touching on the current legislation and secondly to give an overview of why collective bargaining is a necessary tool to balance power in the workplace. I shall examine the discourse as to whether the term "collective bargaining" creates a duty to participate (which can mean compelled) in collective bargaining on the part of the employer, as opposed to a right to engage in collective bargaining (which is voluntary). Lastly, the author will attempt to show the thread of how the courts have answered the question in case law (SANDU I, II and III supra).

\section{Historical overview of collective bargaining}

South Africa has a history of inequality, illegal strikes and non-recognition of Black unions in a workplace. According to Steenkamp, Stelzner and Badenhorst ("The Right to Bargain Collectively" 200425 ILJ 943), the history of labour law in South Africa is rooted in the struggle against apartheid. The racial prejudice and discrimination that permeated all aspects of life, was no less prevalent at the workplace (Steenkamp et al "The Right to Bargain Collectively" 200425 ILJ 943). The period from 1902 to 1924 was marked by a string of labour strikes (Myburgh "100 Years of Strike Law" 200425 ILJ 962). In 1922 an illegal strike erupted on the Rand. Transvaal gold mines hostilities broke between capital and (white) labour culminating in the Rand Rebellion. The precipitating cause of the rebellion was the declared intention of the mine management to dismiss semi-skilled white miners in order to cut the wage bill (Lever Capital and Labour in South Africa: The Passage of the Industrial Conciliation Act (1924); and Myburgh 200425 ILJ 962). 
Subsequent to this strike the Smuts government sought to regulate relations between employers and labour. The government thus promulgated the Industrial Conciliation Act (11 of 1924 (hereinafter "ICA").

Black workers were excluded from the ICA which was the first legislation to regulate collective bargaining (SA National Defence Union $v$ Minister of Defence [2007] 9 BLLR 785 (CC) par [50]). After the promulgation, a committee system for black workers was introduced but Blacks were not included in collective bargaining. This dualistic approach was not successful in deterring industrial unrest. These racialised labour laws even led to growing political tensions. The position of Blacks in the labour market was regulated by the Black Labour Relations Regulation Act (48 of 1953). This Act, inter alia, provided Blacks with a restricted right to strike. Illegal strikes by Black workers ensued and escalated.

The ICA evolved into the Labour Relations Act (28 of 1956; and Bloch The Legislative Framework of Collective Bargaining in South Africa (1979) 63). This new Act gave a basic understanding of unfair labour practices. It was not clear from the Act that the duty to bargain was created. The Industrial Court (hereinafter "IC") could therefore not have a basis to conclude on this aspect (that is, the duty to bargain) as observed in Bleazard $v$ Argus Printing and Publishing Co Ltd (1983 4 ILJ 60 (IC)). (The Industrial Court in some of its decisions created a hybrid system in which collective action to enforce collective bargaining was supplemented by judicial intervention. The soundness of this approach is open to doubt; and see SANDU III 11.) Some members of the IC were not in favour of the imposition of a duty to bargain (Grogan Collective Labour Law (1993) 24); arguing that the judiciary went beyond the provisions of the LRA 1956 in creating such a duty to bargain collectively. In the same year, following the Bleazard decision, the IC was faced with another bargaining dispute in UAMAWU v Fodens (1983 4 ILJ 212 (IC)). In this case the IC ordered the company to commence negotiations in good faith with the union.

It is imperative to note that the notion of a duty to bargain collectively found prominence in the IC "because many employers were reluctant to recognise Black trade unions as legitimate representatives of their workforces". Van Niekerk, Christianson, McGregor, Smit and Van Eck (Law @ Work (2008) 341) affirm that collective bargaining is constantly mutating institutions which are necessarily responsive to economic demands and circumstances, and that the nature and extent of legal intervention to regulate collective bargaining will always reflect particular interests.

In the late seventies the government put together a Commission of Inquiry into labour legislation headed by Professor Wiehahn. (Wiehahn was law teacher at the University of Port Elizabeth. During the 1976 riots Wiehahn persuaded Fanie Botha, the Minister of Labour, to consider reforming South Africa's racialised labour law.) Steenkamp et al (2004 25 ILJ 949) maintain that the turning point in this chequered history of segregation and division was the 1979 report by the Wiehahn Commission. The most revolutionary recommendation of this report was that freedom of association be extended 
to all employees regardless of race, and that Black trade unions be allowed to register (Steenkamp et al 200425 ILJ 949). One of the commission's recommendations informed the newly established Industrial Court and gave content to the concept of an unfair labour practice. Further the commission recommended that labour and practice should correspond with international conventions and codes (Van Jaarsveld, Fourie and Olivier Principles and Practice of Labour Law (2007) 330).

\section{The role of the International Labour Organisation with regard to collective bargaining}

The ILO has played a major role in developing issues related to the right to collective bargaining in South Africa. The right to collective bargaining appears to have followed from the Universal Declaration of Human Rights (hereinafter "UDHR") (Universal Declaration of Human Rights December 10 1948, Article 22-25). A Fact-finding and Conciliation Commission of the ILO investigated the collective bargaining system in South Africa and made a number of recommendations which were incorporated into the recommendations of the Ministerial task team in 1995 and this formed the basis for the 1995 LRA (Van Jaarsveld et al 320). These recommendations have also been incorporated by the courts in interpreting matters dealing with the right to collective bargaining (SANDU I, II and III supra).

With reference to the 2006 SANDU case (SANDU 200611 BLLR 1043 (SCA), Van Niekerk et al (28) observe as follows: "International agreements and customary international law ... provide a framework within which [the Bill of Rights] can be evaluated and understood".

In S v Makwanyane (1995 3 SA 391 (CC) 413-414) the Constitutional Court observed that the Supreme Court of Appeal made specific reference to section (1)(b) when interpreting the Bill of Rights. This section requires a court, tribunal or forum to consider international law. In regard to the Constitution the Supreme Court considered in some detail the provisions of ILO Conventions 87 (Freedom of Association) 98 (right to bargain collectively) and 154 (further developing the right to bargain collectively). This reference recognizes the ILO's position with regard to collective bargaining. Van Niekerk et al (28) further maintain that the main issue was whether the constitutional right to engage in collective bargaining meant that national legislation ought necessarily to establish a duty to bargain. Van Niekerk et al (28) agrees with the conclusion of the court (SANDU I) that both the conventions and the LRA (66 of 1995) do not infringe the constitutional right to engage in collective bargaining by failing to incorporate a compulsion to bargain collectively.

The LRA extends specific recognition to the international law obligations incurred by South Africa by virtue of its membership of the ILO (Van Niekerk et al 28). The ILO does recognise the right to collective bargaining as a human right but not as a duty or obligation that necessitates a law to enforce the right. 
In the human rights tradition of analysis, the right to collective bargaining and the freedom of association are considered "negative rights" in that, for the rights to be respected, the state initially needs not do anything except allow workers to exercise these rights (http://www.dol.gov/ilab/webmils/intl laborstandards/collectivebargaining.html (accessed 2008-10-13). Convention 98 of the ILO protects unionists against employers and goes further to encourage and promote collective bargaining. Van Niekerk et al (11) notes that in this regard the Wiehahn report culminated in the amendments to the 1956 Labour Relations Act. The ILO had a great influence on the drafting of the new LRA.

Explaining the international view on the right to bargain, Vettori ("A Judicially Enforceable Duty to Bargain?" 2005 38(2) De Jure 382-394) states that, "nothing in Article 4 of Convention 98, which deals with the right to organize and bargain collectively, places a duty on the government to enforce collective bargaining by compulsory means with a given organisation; such intervention would clearly alter the nature of bargaining".

Davis, Cheadle and Haysom (Fundamental Rights in the Constitution (1997) 390) argue that the duty to bargain is not an aspect of the right to bargain collectively in the manner articulated in international instruments such as the ILO Conventions. Davis et al further state that the ILO Convention on the right to organise and to bargain collectively records the ratifying member's obligations as follows:

"This obligation has been glossed by the Committee on Freedom of Association. The Committee states, in this its digest of decisions, that collective bargaining if it is to be effective, must assume a voluntary character and not entail recourse to measures of compulsion which would alter the voluntary nature of such bargaining" (Davis et al 390).

This view is a trend followed by writers and is in total agreement with both the international and national instruments on the right to collective bargaining. (The Constitutional Court highlighted the role of industrial action in the first certification judgment, Ex parte Chairman of the Constitutional Assembly: In re Certification of the Constitution of the Republic of SA, 1996 4 SA 744 (CC); 199617 ILJ 821 (CC).)

Consequently, the United Nations Global Compact has come up with ten principles which deal with fundamental issues in the workplace. (This is a committee of the UN. The labour principles of the Global Compact are taken from the ILO's Declaration on Fundamental Principles and Rights at Work. This Declaration was adopted in 1998 by the International Labour Conference, a yearly tripartite meeting that brings together governments, employers and workers from 177 countries: http://www.unglobalcompact.org/ AboutTheGC/TheTenPrinciples/labourStandards.html (accessed 2008-08$08)$ ). The challenge for business is to take these universally accepted values that are founded in the principles, and apply them at the company level. Principle number three reads as follows: "[T]o promote and realise in good faith the right of workers and employers to freedom of association and the effective recognition of the right to collective bargaining" (Davis et al 390). 
Hence, the ILO urges member states and now companies to indulge in the promotion, realization and recognition of the right to bargain, however, it is not penned anywhere that these rights are mandatory. It is imperative to note that while these rights are said to be "negative" by human rights standards; they need to be protected through "positive" means. The Constitution portrays such positive means for the protection of the right to bargain collectively, as will be discussed next.

\section{The development of collective bargaining under the 1996 Constitution}

The Bill of Rights as contained in Chapter 2 of the Constitution of the Republic of South Africa, 1996 (hereinafter "the Constitution") bears pertinent provisions called equality clauses. The provisions of section 23 give everyone the right to fair labour practices (s 23(1)). The provisions include employers and the workers. Currie and De Waal (The Bill of Rights Handbook (2005) 499) aver that the most significant amendments, brought about by section 23 of the final Constitution are the recasting of the collective bargaining provisions to conform to the principle of equality contained in the Constitution.

Based on South African labour history, it is trite that the objective of the drafters of the Constitution was to encourage consensus among the various actors of collective bargaining in a labour environment. (Van Jaarsveld et al 321 agree that the whole scope of collective labour law raised special public interest in 1977 and again in 1994 with the appointment of the Wiehahn Commission and the Ministerial Task team, respectively. See Kooy, Horner, Green and Miller "Wiehahn Commission: A Summary" 1979 South Africa Labour and Development Research Unit 10.) The rationale behind collective bargaining according to the Constitutional Court (CC) and the Supreme Court of Appeal (SCA) is based on the recognition of the fact that employers enjoy greater social and economic power than individual workers do. (It is correct that collective bargaining implies a right on the part of those who engage in collective bargaining to exercise economic power against their adversaries. However, CP [Constitutional Principle] XXVIII does not require that the NT [New Text] expressly recognise any particular mechanism for the exercise of economic power on behalf of workers or employers: it suffices that the right to bargain collectively is specifically protected. See SANDU III 12.) The workers therefore need to act in concert to provide them with sufficient power to bargain collectively and effectively with employers ( $E x$ parte Chairman of the Constitutional Assembly: In re Certification of the Constitution of the Republic of SA, 1996199617 ILJ 821 (CC) par 66). The notion of collective bargaining is one of the main objects of labour law and it is the countervailing force that balances the inequality in bargaining (Davies and Freedland Kahn-Freund Labour and the Law 3ed (1983) 18).

Section 23(5) of the Constitution refers to a right to engage in collective bargaining. It is prudent to argue that the Constitution makes no specific 
provision in favour of a duty to bargain collectively, nor does it provide for a duty to bargain in good faith. The right to engage in collective bargaining imposes a freedom to bargain collectively. A duty is defined as "what one is bound to by any obligation to do" (Chambers Twentieth Century Dictionary). It is noteworthy that both the LRA and the Constitution do not make reference to a duty to engage in collective bargaining.

Having alluded to the constitutional abstention concerning the duty to bargain collectively but for the right to engage in collective bargaining, there is a case to make therefore that the Constitution prefers voluntarism in collective bargaining. The LRA, as a mechanism to give effect to the entrenched right as found in the Constitution, is a law of general application to entertain aspects as well as their interpretation.

\section{The interpretation of the Labour Relations Act 66 of 1995 regarding collective bargaining}

In South Africa the right to bargain collectively is regulated in two principal ways, namely through the LRA (s 65 of the Act does not explicitly define collective bargaining; however, it encourages collective agreements which emerge as a result of collective bargaining) and the Constitution. The function of the judiciary (SANDU I,II and III supra) in this regard is to interpret the right as set out in the Constitution and the LRA.

The drafters of the LRA addressed and determined how the two main actors in collective bargaining, namely, the industry and the trade unions, are to interact, including the rules and procedures that they utilise in collective bargaining. The current LRA does not contain an obligation to negotiate in good faith. It provides for the right to freedom of association and organisational rights that may assist trade unions in the establishment of a bargaining relationship, the registration of trade unions and employer's organisations and the right to strike.

Under these circumstances, legal regulation may be critical to the operation of trade unions and the collective bargaining process. Conversely, Le Roux ("Statutory Councils: Their Powers and Functions" 1996 5(7) Contemporary Labour Law 61) in interpreting Chapter III of the LRA, avers that a compromise was reached by means of the powerful incentives to bargain in terms of the LRA. These are:

- that in general, bargaining remains voluntary. In Part E of Chapter III, however, the unions contributed to the compulsory establishment of statutory councils in certain instances;

- a preference for centralised forms of bargaining within the bargaining councils; and

- that the collective bargaining role of these bodies, however, be limited to accommodate employers' autonomy in the process. 
The LRA at section 64(2) provides the types of refusal to bargain on an issue in dispute. Consequently the LRA provides that such refusal may culminate in a strike or lock-out. Therefore, parties cannot be compelled by the courts to bargain collectively as strikes and lock-outs are in place to encourage self-regulation and joint problem-solving by the parties (Steenkamp et al 200425 ILJ 949). However, Van Jaarsveld et al (543) warns that there are some instances where the LRA does not encourage voluntarism at all, as the Minister may force parties to become members of a statutory council and in this manner force the parties to bargain with each other. The system as portrayed by the legislator in the LRA is not to impose a duty on the employer but, to "adopt an unashamedly voluntarist approach" (Brassey Employment and Labour Law Vol 3 (2000) A1:8).

It has become apparent that some of the incentives for bargaining have been emphasised by court interpretations. In Bader Bop (Bader Bop (Pty) Ltd v NUMSA 200223 ILJ 104 (LAC); and NUMSA v Bader Bop (Pty) Ltd $23302103(C C)$ ), the applicant which is a minority trade union, approached the Constitutional Court, arguing that on the interpretation of the relevant provisions of the LRA 1995, section 23(1)(c) provides that a collective agreement binds members of a registered trade union and the provisions of section 23(1)(c) constitute an infringement of their right to strike. In the decision O'Regan $\mathrm{J}$ held that NUMSA (the minority trade union) was entitled "to embark on a strike in pursuit of such organisational rights". The Constitutional Court recognised the importance of collective bargaining in ensuring fair labour relations. Therefore, collective bargaining and fair labour relations need to be regulated as opposed to being constricted.

\section{Regulation versus de-regulation}

The regulation of collective bargaining is a subject of controversy. Brassey (181) opines that our labour relations are extensively regulated; however, this is not without restricted judicial intervention which poses itself as a "regulatory factor". The regulation vis-ó-vis deregulation debate has erupted again in the SANDU I, II and III cases (O'Regan J in South African National Defence Union v Minister of Defence 200728 ILJ 1909 (CC) par [5]).

Davies and Freedland (18) in quoting Kahn-Freund, emphasise the role of the legislator and the courts in the development of labour relations within the policy of self-restraint or laissez-faire. Laissez-faire according to KahnFreund (Davies and Freedland 18), means allowing free play to the collective forces of society and limiting the intervention of the law to those marginal areas in which the forces of organised labour and management are so great as to prevent the successful operation of what is so very characteristically called negotiating machinery. Landman ("Labour's Right to Employer Information" October 1996 6(3) Contemporary Labour 21-25) calls this "power play" which is clearly the approved method for enforcing any notion of a demand to bargain. 
The law itself can do little to equalise the imbalance. In general, workers can match the power of their (often corporate) employers only by acting collectively. Not only does this put them in a bargaining position, but it is also necessary to enforce their rights in practice. "Legal norms", as Kahn-Freund put it, "cannot often be effective unless they are backed by ... the countervailing power of trade unions and of the organised workers" (Davis et al 390). The employer's economic muscle and the workers' strike are a platform for bargaining interaction if regulated within a limited legal framework. Davies and Freedland (45) admit that collective bargaining depends on the unions more than the unions depend on the effectiveness of the law. From this standpoint, the role of the law is to create space for collective bargaining to evolve and not to impose it on the employer (author's own emphasis). The courts should therefore show "a degree of deference" to the institutions of collective bargaining, recognising "the complexity and delicacy of the balance sought to be struck by legislation among the interests of labour, management, and the public" (Davis et al 390).

\section{Voluntarism and compulsion}

As shown above, the South African Constitution is more inclined towards the voluntaristic system when it deals with collective bargaining. Although Conradie JA (Minister of Defence v SANDU 20071 SA 422 (SCA); and SANDU III 11) maintains that voluntarism does not mean that employers and employees necessarily negotiate voluntarily, but that they negotiate in order to avert the economic pressures brought about by a strike or a lock-out. This pressure is one of the principal driving forces behind the voluntarist system.

Ndumo (The Duty to Bargain and Collectively Bargain in South Africa, Lesotho and Canada: Comparative Perspective (2005) 73) avers that there are two schools of thought with regard to the issue of collective bargaining, namely voluntarism and compulsion. He argues that some members of the academia and of the judiciary are opposed to a statutorily imposed duty to bargain collectively, while trade unions and certain commentators support a legal duty to bargain collectively (Jordaan The New Constitution and Labour Law (1996) 2; and Mischke "Getting a Foot in the Door: Organisational Rights and Collective Bargaining in Terms of the LRA" 2004 Contemporary Labour Law 51). Ndumo (73) concludes that the nature of voluntarism that prevails in South Africa is a regulated voluntarism which is applied by the courts.

Voluntarism and compulsion are the actionary and the reactionary aspects of interaction in collective bargaining interplay. In appropriate circumstances, this interplay requires a subsequent role of the court. 


\section{The role of the court in interpreting the right to engage in collective bargaining SANDU 1}

In SANDU 1 (SANDU v Minister of Defence 20033 SA $239(\mathrm{~T})$ ) the High Court was saddled with a task of determining, inter alia, whether the applicant had shown that the respondents were indeed under a duty to bargain or to engage collectively until deadlocked in terms of the Constitution. In this case Van der Westhuizen J, took a view contrary to SANDU's position. The court was grappling with the two main interpretations mentioned above.

Van der Westhuizen $\mathrm{J}$ first distinguished between the wordings of the interim Constitution and the final Constitution. The former at section 27(3) provided for the right to bargain collectively, whereas the latter recognises the right to engage in collective bargaining, Van der Westhuizen $\mathrm{J}$ interpreted that the distinction between the right to collective bargaining and the right to engage in collective bargaining is a fine one. The court further suggested that collective bargaining is best if left to the power play between the parties as the Courts are being ill-suited to take decisions which might interfere with the process. In casu, the Court relied heavily on the meaning of "engage" (s 23(5) of the Constitution), which in the Court's mind, connotes a freedom and does not therefore impose a correlative obligation on another to engage in collective bargaining.

\section{SANDU II (TPD)}

The decision of Van der Westhuizen $\mathrm{J}$ was overturned by Smith $\mathrm{J}$ in SANDU II (SANDU v Minister of Defence 20044 SA 10 (T)). Smith J decided in favour of the union SANDU. In SANDU // the court contended that section 23(5) affords a union a right to engage in collective bargaining with an employer as well as imposing a correlative duty to bargain on the SANDF SANDU II (SANDU v Minister of Defence supra).

The court's reasoning in this case was that the duty to bargain in good faith is associated with and is integral to collective bargaining. As SANDU has a right to engage in collective bargaining in terms of the provisions of section 23(5) of the Constitution, the conferral of such a right must impose a correlative duty on the other party, including the state, since the right binds the state according to section 8(1) of the Constitution. Collective bargaining is likened to a "tango dance". The parties to collective bargaining must be in unison and in step, thus displaying good faith in how they interact with one another (Grogan (editor) "It Takes Two to Bargain: Military Unions March Forward" 2004 20(3) EL 11).

\section{SANDU III}

Given the two conflicting decisions handed down in SANDU I and SANDU II, SANDU launched an application for an interdict to prevent SANDF from 
implementing a policy unilaterally without first engaging in a bargaining process with the union. Bertelsmann $\mathrm{J}$ heard the application in the High Court and agreed with Smith $J$ that SANDF did have a duty to bargain with SANDU. The appeals from SANDU I, II and III were heard in the Supreme Court of Appeal (Minister of Defence v SANDU 20071 SA 422 (SCA)). The court agreed with the decision in SANDU II. Conradie JA concluded that "the Constitution does not impose on employers or employees a judicially enforceable duty to bargain and that it does not contemplate that, where the right to strike is removed or restricted, but is replaced by another adequate mechanism, a duty to bargain arises" (South African National Defence Union $\checkmark$ Minister of Defence; Minister of Defence $v$ South African National Defence Union 20071 SA 402 (SCA) 25). The SCA in this light endorsed Smith J's notion of a duty to bargain collectively.

\section{SANDU (2007) (SANDU v Minister of Defence 20075 SA 400 (CC) 41)}

The approach by the Constitutional Court was based on the legislation enacted to regulate the right to collective bargaining. Constitutional Court's O'Regan $\mathrm{J}$ contended that to permit the litigant to ignore the legislation and rely directly on the constitutional provision would be to fail to recognise the important task conferred upon the legislature by the Constitution. Subsequent to this explanation the Constitutional Court refrained from determining the proper interpretation of section 23(5) of the Constitution (SANDU CC 2007 supra 56).

The Constitutional Court, in its order (SANDU supra 106) addressing one of the core issues, almost invariably set aside the decisions in SANDU I, II and III. The order made by the Constitutional Court suggests that once the bargaining process has resumed it is trite that the parties bargain in good faith. Therefore it is not expected of a party to wield its power by leaving or threatening to abandon the bargaining. However, the Constitutional Court's order in this instance does not in itself suggest a "duty to bargain". This order of the court is a bit ambivalent, as it does not specifically address the question of the opposing interpretations relating to collective bargaining.

\section{Conclusion}

In South Africa the impact of the Constitution on collective bargaining has been interpreted by the courts (SANDU II and III supra) to mean the imposition of a duty to bargain on the part of the employer. Conversely section 23(5) has been interpreted in some quarters to give a voluntaristic nature to collective bargaining. The voluntary nature of the right makes a modest contribution to promote good labour relations. The introduction of regulated voluntarism into the South African labour, as is missing in the LRA, could enhance security for all parties in collective bargaining. 
Clearly the current LRA does not provide for a judicially enforceable duty to bargain. It also does not make the imposition of that duty possible in that it promotes or encourages collective bargaining through an "economic/ industrial muscle" (Davis et al 390) in the form of a strike. The strike is a vehicle to counter the refusal of the employer to bargain.

As stated above (Davis et al 390), the law plays an enabling role in the development of collective bargaining. Furthermore it is the interaction of employers and organized labour that will ultimately determine the law's content and effect. More particularly, effective trade union organisation is crucial. Bendix (Industrial Relations in the New South Africa (1998) 102) opines that the extent to which the state will interfere in the labourmanagement relationship will depend generally on its adherence to the principle of voluntarism on the one hand or mandatorism on the other. The LRA does not suggest a mandatory approach to the collective bargaining. Sections 11 up to 66 of the LRA (Chapter III - the provisions of these sections are mainly focused on the rights of the trade union and bargaining councils) provide for the role of the legislation in this regard. These sections determine the way in which the actors interact as contained in the rules and procedures concerning collective bargaining.

A good example of a regulated voluntaristic approach is the SANDF case referred to above. The SANDF case is a special example in that it falls outside of the ambit of the LRA. Employees of SANDF are therefore denied a right to strike. Collective bargaining is accordingly their only means of raising and resolving issues of mutual concern.

Angela Patricia Molusi University of South Africa (UNISA) 